\title{
Biological response to iron fertilization in the eastern equatorial Pacific (IronEx II). III. Dynamics of phyto- plankton growth and microzooplankton grazing
}

\author{
M. R. Landry ${ }^{1, *}$, J. Constantinou1 ${ }^{1}$, M. Latasa ${ }^{2}$, S. L. Brown ${ }^{1}$, R. R. Bidigare ${ }^{1,3}$, \\ M. E. Ondrusek ${ }^{4}$ \\ ${ }^{1}$ Department of Oceanography, University of Hawai'i at Manoa, Honolulu, Hawai'i 96822, USA \\ ${ }^{2}$ Institut de Ciències del Mar, Passeig Joan de Borbó s/n, 08039 Barcelona, Spain \\ ${ }^{3}$ Hawai'i Institute of Marine Biology, PO Box 1346, Kaneohe, Hawai'i 96744, USA \\ ${ }^{4}$ DOC/NOAA/NESDIS, E/RA30, 5200 Auth Rd. Camp Springs, Maryland 20746, USA
}

\begin{abstract}
Phytoplankton growth and microzooplankton grazing were investigated during the IronEx II mesoscale enrichment experiment using the seawater dilution technique combined with groupspecific pigment markers. Growth rate estimates for the phytoplankton community increased $\geq 2$-fold, from $0.6 \mathrm{~d}^{-1}$ in the ambient environment to $1.2-1.6 \mathrm{~d}^{-1}$ in the iron-enhanced bloom. Grazing lagged growth, allowing phytoplankton biomass to accumulate at a high rate $\left(\sim 0.8 \mathrm{~d}^{-1}\right)$ initially. However, grazing mortality ultimately increased 3- to 4 -fold to 1.2-1.4 $\mathrm{d}^{-1}$, largely balancing growth by Day 6 of the experiment. Increased rates were broadly distributed among phytoplankton taxa, but they differed in timing. Whereas picophytoplankton showed more of a steady balance between growth and grazing, increasing grazing pressure on diatoms followed a 3-5-fold increase in larger $(>20 \mu \mathrm{m})$ heterotrophic dinoflagellates and ciliates, which grew in response to enhanced diatom biomass. In the ambient environment, phytoplankton production was 15 to $20 \mu \mathrm{g} \mathrm{C} \mathrm{l}^{-1} \mathrm{~d}^{-1}$, with diatoms accounting for $17 \%$ of growth and $7 \%$ of grazing losses. Total phytoplankton production increased to $150-200 \mu \mathrm{g} \mathrm{Cl}^{-1} \mathrm{~d}^{-1}$ at the peak of the patch bloom, where $79 \%$ of growth and $55 \%$ of microzooplankton grazing involved diatoms. Phytoplankton grazing mortality was significantly correlated with grazer biovolume, and high carbon-specific grazing estimates at the bloom peak indicated growth rates $\sim 1.0 \mathrm{~d}^{-1}$ for the heterotrophic community and up to $1.4 \mathrm{~d}^{-1}$ for $>20 \mu \mathrm{m}$ heterotrophs. During several days when high phytoplankton biomass was relatively constant in the patch bloom, the pennate diatom dominated the community and remained physiologically healthy and growing at a fast rate, even though nutrient conditions were suboptimal. Efficient cropping of diatoms by large protistan grazers and rapid remineralization of iron and biogenic silica were required to maintain this dynamic balance. Contrary to expectations, the carbon export ratio did not increase with the iron-induced diatom bloom. Thus, mesoscale iron-enrichment of high-nutrient, low chlorophyll waters in the eastern equatorial Pacific clearly demonstrated that phytoplankton growth rates and standing stocks were iron-limited. However, the food web also demonstrated a remarkable resiliency to environmental perturbation by establishing a new balance in which the essential features of a microzooplankton-dominated, low export system were maintained.
\end{abstract}

KEY WORDS: Marker pigments $\cdot$ Production $\cdot$ Iron-limitation $\cdot$ Grazing regulation $\cdot$ Ciliates $\cdot$ Dinoflagellates · Diatoms

Resale or republication not permitted without written consent of the publisher

\section{INTRODUCTION}

Recent analyses of the ocean's high-nutrient, lowchlorophyll (HNLC) regions have emphasized the dual

*E-mail: landry@soest.hawaii.edu regulatory influences of iron limitation and grazing (Cullen 1991, Morel et al. 1991, Price et al. 1994, Landry et al. 1997). As a limiting resource for which cells of different size must compete, iron is thought to affect most severely the growth and physiology of large phytoplankton. On the other hand, maintaining high growth 
rates of small phytoplankton, despite extremely low concentrations of iron in the ambient environment, requires continuous balanced removal and efficient remineralization of these cells by protistan grazers (Frost \& Franzen 1992). General features of the phytoplankton bloom response to iron fertilization in the equatorial Pacific (IronEx II) - the explosive increase in diatoms, the shift to larger cells, and the relative constancy of community composition below $10 \mu \mathrm{m}$ cell size (Coale et al. 1996, Landry et al. 2000, in this issue) - are consistent with expectations from these control mechanisms. Nonetheless, the net changes in different types and sizes of phytoplankton cells in the IronEx II patch provide little insight into the underlying dynamics of community response and regulation.

The present study describes how iron addition to HNLC equatorial waters affected the growth rates and microzooplankton grazing losses of different phytoplankton functional groups, distinguished by their accessory pigmentation. Based on observed physiological responses of the ambient phytoplankton community in the IronEx I experiment (Greene et al. 1994, Kolber et al. 1994, Martin et al. 1994), we expected that iron might elicit enhanced growth of smaller phytoplankton dominants but that protistan grazing would maintain a robust control on them in the iron-perturbed ecosystem. Our experiments were meant to test these expectations. In addition, after $6 \mathrm{~d}$ of consistently high exponential increase, diatom biomass was observed to level off at a relatively constant high level at the peak of the IronEx II patch bloom (Landry et al. 2000). Therefore, our process-oriented measurements were also relevant to evaluating whether this plateau was a consequence of reduced (nutrient-limited) growth and/or grazing regulation. Latasa et al. (1997) previously reported evidence of high diatom growth rate and utilization by microzooplankton in HNLC equatorial waters. In the present study, protistan grazing appears to provide an explanation for reduced diatom net growth at the peak of the bloom, with potentially important implications for the translation of the iron-induced biomass bloom into carbon export.

\section{MATERIALS AND METHODS}

Experimental setup. All experimental containers and transfer tubing (silicone) were precleaned with a modified Fitzwater et al. (1982) protocol involving sequential overnight soaks in Micro detergent-deionized water, $10 \% \mathrm{HCl}$ Milli-Q water (2 times), and 2\% nitric acid-Milli-Q water, with intermediate rinses with Milli-Q water and final rinses ( 3 times) with quartz-distilled water. The items were soaked between uses in $10 \% \mathrm{HCl}$ Milli-Q water, and rinsed 3 times with freshly collected seawater prior to use. Plastic gloves were worn during all phases of experimental setup, subsampling and cleaning.

Seawater was collected at $15 \mathrm{~m}$ depth in 30 l, Teflonlined Go-Flo bottles on a trace-metal clean CTD rosette. Filtered water was obtained by direct gravity flow from the Go-Flo bottles through an in-line filter capsule (Gelman Criticap 100, $0.2 \mu \mathrm{m}$ pore size, presoaked for $1 \mathrm{~h}$ in $10 \% \mathrm{HCl}$ ) to a clean polycarbonate carboy.

Dilution experiments were prepared similarly to Landry et al. $(1995,1998)$. Each experiment was set up in $162.1 \mathrm{l}$ polycarbonate bottles. Ten of the bottles were used as nutrient-enriched dilution treatments consisting of replicated bottles with $0.22,0.45,0.65$, 0.86 and 1.0 natural (unfiltered) seawater with an added nutrient mixture of $0.5 \mu \mathrm{M} \mathrm{N}$-ammonium, $0.03 \mu \mathrm{M}$ phosphate, $1.0 \mathrm{nM}$ iron $\left(\mathrm{FeSO}_{4}\right)$, and $0.1 \mathrm{nM}$ manganese $\left(\mathrm{MnSO}_{4}\right)$ to promote constant phytoplankton growth. One of the remaining 6 bottles was filled with filtered seawater and run as a control to account for organisms that passed through the filter (Li 1990). The remaining 5 were filled carefully without nutrient enrichment. Three of these were sacrificed for initial samples, and the final 2 were incubated as natural seawater controls. All experimental bottles were tightly capped after filling and incubated for $24 \mathrm{~h}$ in shipboard seawater incubators constructed of light blue Plexiglas (color 2069). These incubators transmitted $30 \%$ of incident PAR and were meant to simulate as closely as possible the ambient temperature and light conditions in the middle of the mixed layer, which extended to $25 \mathrm{~m}$ at the start of the experiment.

Pigment analyses. Initial and final bottles were subsampled for fluorometric chl a (130 or $280 \mathrm{ml}$ samples) and HPLC pigments (1.8 l samples). Chl a samples $(280 \mathrm{ml})$ were also taken routinely from the initial filtered water and the incubated filtered treatment and always showed negligible concentrations. Fluorometric chl a samples were filtered onto $25 \mathrm{~mm}$ Whatman GF/F glass fiber filters, extracted in $10 \mathrm{ml}$ of $90 \%$ acetone with water for $24 \mathrm{~h}$ at $-20^{\circ} \mathrm{C}$, and measured with a Turner Designs fluorometer using equations calibrated against HPLC-determined chl a. These shipboard measurements were useful for monitoring experimental results during the cruise, but since fluorometric and HPLC analyses of chl a agreed closely, we only present HPLC results here.

HPLC pigment samples were filtered under positive pressure ( $<0.3$ bar) onto $25 \mathrm{~mm}$ GF/F filters, frozen in liquid $\mathrm{N}_{2}$, and stored at $-85^{\circ} \mathrm{C}$ until analysis. Filters were sonicated $\left(0^{\circ} \mathrm{C}\right.$, dark $)$ in $3 \mathrm{ml}$ of $100 \%$ acetone with $50 \mu \mathrm{l}$ of canthaxanthin in acetone added as an internal standard. Pigments were then extracted in the dark at $0^{\circ} \mathrm{C}$ for $24 \mathrm{~h}$. Prior to analysis, pigment extracts were vortexed and centrifuged to remove cellular debris. 
Pigment concentrations were determined by reverse phase, high-performance liquid chromatography following the method of Latasa et al. (1996). Subsamples of $200 \mathrm{\mu l}$ of a mixture of $1.0 \mathrm{ml}$ pigment extract plus $0.3 \mathrm{ml} \mathrm{H}_{2} \mathrm{O}$ were injected into a Varian 5000 HPLC system equipped with autosampler, Timberline column heater $\left(26^{\circ} \mathrm{C}\right)$ and Spherisorb $5 \mu \mathrm{m}$ ODS2 analytical and guard columns. Pigments were measured with Thermo Separation Products UV2000 absorbance (436 and $450 \mathrm{~nm}$ ) and FL2000 fluorescence $\left(\lambda_{\text {ex }}: 410 \pm\right.$ $40 \mathrm{~nm}, \lambda_{\text {em }}: 600$ to $800 \mathrm{~nm}_{\text {; }}$ custom Omega Optical filters) detectors. Separations followed the ternary solvent protocol (eluent $A=80: 20$ mixture of methanol: $0.5 \mathrm{M}$ ammonium acetate; eluent $\mathrm{B}=80: 15$ mixture of acetonitrile:water; eluent $\mathrm{C}=$ ethyl acetate; all mixtures as vol:vol) (Latasa et al. 1996, 1997). Peak identifications were made by comparing the retention times of eluting peaks with those of pure standards and by the absorbance and fluorescence spectra of peaks scanned during the chromatographic analysis. Since the above procedures did not distinguish monovinyl

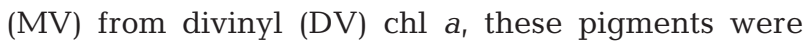
optically resolved from absorbances at 436 and $450 \mathrm{~nm}$ and the dichromatic equations of Latasa et al. (1996).

Protistan grazers. Composition and biomass structure of the protistan grazer assemblage were assessed throughout the IronEx II study, but not all components were measured from the same hydrocast. For the present experiments, initial $250 \mathrm{ml}$ samples from the dilution hydrocast were preserved with $5 \%$ Lugol's iodine solution. These samples were analyzed as described below for abundances, biovolumes and carbon biomass of ciliates and dinoflagellates. Heterotrophic nanoflagellates (2 to $20 \mu \mathrm{m}$ ) and other small protists were quantified from epifluorescence microscopical analyses of gluteraldehyde preserved samples (25 to $50 \mathrm{ml})$ taken from the same depth $(15 \mathrm{~m})$, but typically from a hydrocast 1 to $2 \mathrm{~h}$ before water was collected for dilution experiments (methods as described by Landry et al. 2000).

Lugol's preserved subsamples of $100 \mathrm{ml}$ were settled in Utermöhl chambers, and the cells were enumerated and measured at $400 \times$ with a Zeiss inverted microscope. The biovolume distributions for each protist group were determined from measured dimensions of 50 to 100 organisms and formulas for the closest geometric shapes. Ciliate biovolumes were converted to

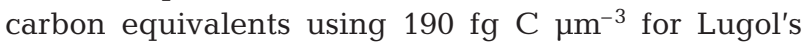
preserved cells (Putt \& Stoecker 1989). Dinoflagellate counts were partitioned into autotrophic and heterotrophic categories based on the percentages of $>20 \mu \mathrm{m}$ pigmented and nonpigmented cells in glutaraldehydepreserved samples analyzed by epifluorescence microscopy (Landry et al. 2000). Dinoflagellate biovol-

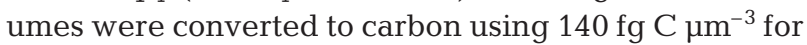

$>20 \mu \mathrm{m}$ cells (Lessard 1991). For calculations of biovolume-specific clearance rates, preserved biovolume estimates were multiplied times 1.28 to correct for cell shrinkage (Putt \& Stoecker 1989).

Rate analyses. Initial pigment concentrations in the dilution treatments were determined from measured concentrations in the initial bottles, the filtered water carboy, and the volumes of natural and filtered water in the dilution mixtures. For each pigment measured, linear regressions of net growth rate against dilution factor (proportion of natural seawater in the dilution treatment) yielded estimates of phytoplankton growth with added nutrients ( $\mu_{\mathrm{n}}=y$-axis intercept) and phytoplankton mortality due to microzooplankton grazing ( $m=$ regression slope) (Landry et al. 1995, 1998). The mortality estimate $(m)$ was subsequently added to the mean net growth rate $\left(k_{0}\right)$ for the unamended natural seawater treatments to determine phytoplankton growth without added nutrients $\left(\mu_{0}=k_{0}+m\right)$. The rate estimates reported here are for measured pigments. We did, in fact, also analyze the results in terms of chl a equivalents of specific taxa (diatoms, prymnesiophytes, etc.) using the CHEMTAX algorithm (Mackey et al. 1996). CHEMTAX pigment assignments introduced another level of uncertainty in the analyses for non-dominant groups (Landry et al. 2000) and confounded regression statistics for some experiments. However, the overall results were similar.

Instantaneous rates of phytoplankton community growth and grazing mortality were used to compute

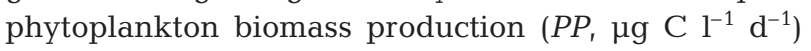
and grazing losses $\left(G, \mu \mathrm{C} \mathrm{l}^{-1} \mathrm{~d}^{-1}\right)$ according to the following equations (Landry \& Hassett 1982, based on Frost 1972):

$$
\begin{aligned}
P P & =\mu_{\mathrm{o}} \times C_{\mathrm{m}} \\
G & =m \times C_{\mathrm{m}}
\end{aligned}
$$

and $\quad C_{\mathrm{m}}=\operatorname{chl} a_{\mathrm{o}}[\mathrm{C}: \mathrm{chl} a]\left[\mathrm{e}^{(\mu-\mathrm{m}) t}-1\right] /\left(\mu_{\mathrm{o}}-m\right) t$

where $C_{\mathrm{m}}$ is the geometric mean concentration of phytoplankton carbon during the experiment, $t=$ time (d), chl $a_{\mathrm{o}}$ is the initial chl a concentration, and C:chl $a$ is the carbon to chl a ratio as determined from microscopical biovolumes (Landry et al. 2000). Carbonbased estimates of diatom production and grazing losses were calculated similarly, substituting $\mu_{\mathrm{o}}$ and $m$ estimates for the marker pigment fucoxanthin and using microscopical estimates of diatom carbon for initial standing stocks.

From Landry $(1981,1993)$, the measured mortality coefficient, $m\left(\mathrm{~d}^{-1}\right)$, is the product of the mean individual clearance rate $\left(F=\right.$ volume cleared of prey ind. ${ }^{-1}$ $\left.\mathrm{d}^{-1}\right)$ and the geometric mean density of grazers $\left(D_{\mathrm{m}}=\right.$ ind. $\mathrm{vol}^{-1}$ ), i.e., $m=F \times D_{\mathrm{m}}$. In the present experiments, $D_{\mathrm{m}}$ was not rigorously quantified because grazers abundances and biovolumes were not measured at the 
end of the incubations. However, the magnitude of this uncertainty was judged to be small (+8\% correction to initial densities, on average) based on the net rates of change in adjacent field samplings and the estimated mortality impacts of mesozooplankton predators (Rollwagen Bollens \& Landry 2000, in this issue). Therefore, we used grazer biomass in initial samples as reasonable approximations of $D_{\mathrm{m}}$.

\section{RESULTS}

\section{Phytoplankton community rates}

$\mathrm{Chl} a$ is the common basis for relating responses in phytoplankton community standing stocks, growth rates and grazing losses to micro- and mesozooplankton in the IronEx II study. In addition to its relevance to interpretations of community dynamics, a more detailed presentation of experimental results for chl a will also illustrate the underlying principles of the analysis for other pigments. 'Control' experiments, for instance, showed a relatively consistent pattern of behavior for chl $a$ in the ambient (unfertilized) community (Fig. 1). Nutrient-amended growth rates, shown as $y$-axis intercepts in the regression equations, varied modestly between 0.5 and $0.8 \mathrm{~d}^{-1}$ and averaged $0.64 \mathrm{~d}^{-1}$ for the 5 experiments. Grazing mortality estimates, shown as the slopes of the regression equations, ranged from 0.2 to $0.4 \mathrm{~d}^{-1}$ with the suggestion of an increasing trend with time. The generally close agreement between net growth rates from nutrient-amended and no-nutrient treatments indicates that the intended nutrient (and iron) additions had little demonstrable effect on growth rate estimates for the $24 \mathrm{~h}$ experimental incubations.

The net growth rates observed in undiluted treatments (Dilution Factor $=1.0$ ) indicates that a substantial component of pigment growth in the incubation bottles, averaging $0.3 \mathrm{~d}^{-1}$, was not balanced by grazing losses to microzooplankton. Some of this 'excess growth' accumulates slowly as a net chl a increase in the ambient community ( $\sim 0.03 \mathrm{~d}^{-1}$; Landry et al. 2000), and $0.06 \mathrm{~d}^{-1}$ is lost on average to mesozooplankton grazing (Rollwagen Bollens \& Landry 2000). Cell sinking losses are assumed to be low $\left(\sim 0.01 \mathrm{~d}^{-1}\right.$; Landry et al. 1997). Potential losses to water-column mixing can be constrained from the dissipation of the inert tracer, $\mathrm{SF}_{6}$, which showed an order-of-magnitude decline during the first $8 \mathrm{~d}$ of the IronEx II experiment, about $60 \%$ to the atmosphere (Coale et al. 1996). The remaining factor-of-4 dilution sets an upper bound on mixingrelated losses of $0.17 \mathrm{~d}^{-1}$. At least half of this loss can be ascribed to a doubling of the mixed layer, and some of the remainder must have diffused laterally. Therefore, the actual loss of cells from the euphotic zone by mix-
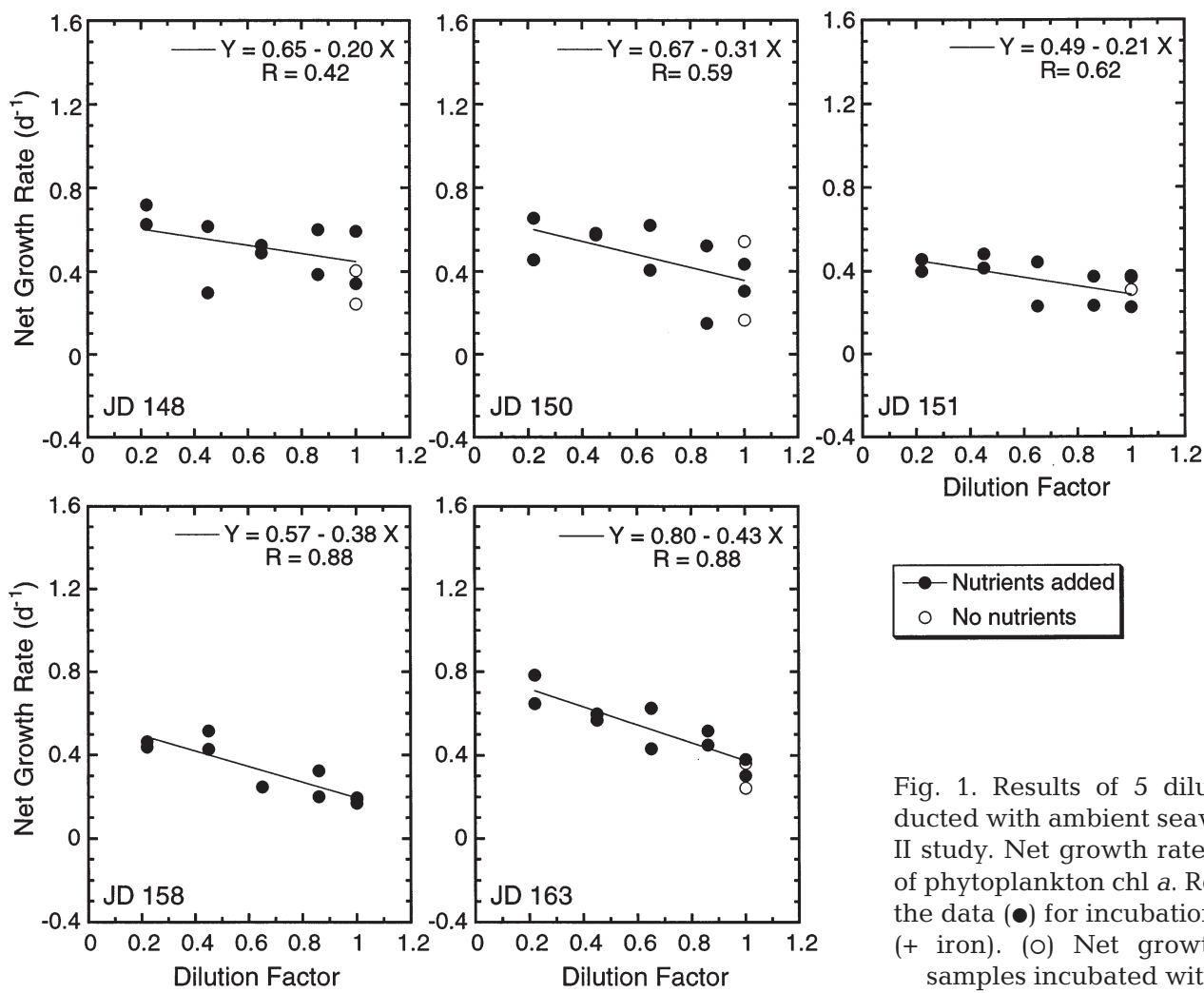

Fig. 1. Results of 5 dilution experiments conducted with ambient seawater during the IronEx II study. Net growth rates from HPLC estimates of phytoplankton chl a. Regression lines are fit to the data $(\bullet)$ for incubations with added nutrients (+ iron). (०) Net growth rates for undiluted samples incubated without added nutrients 

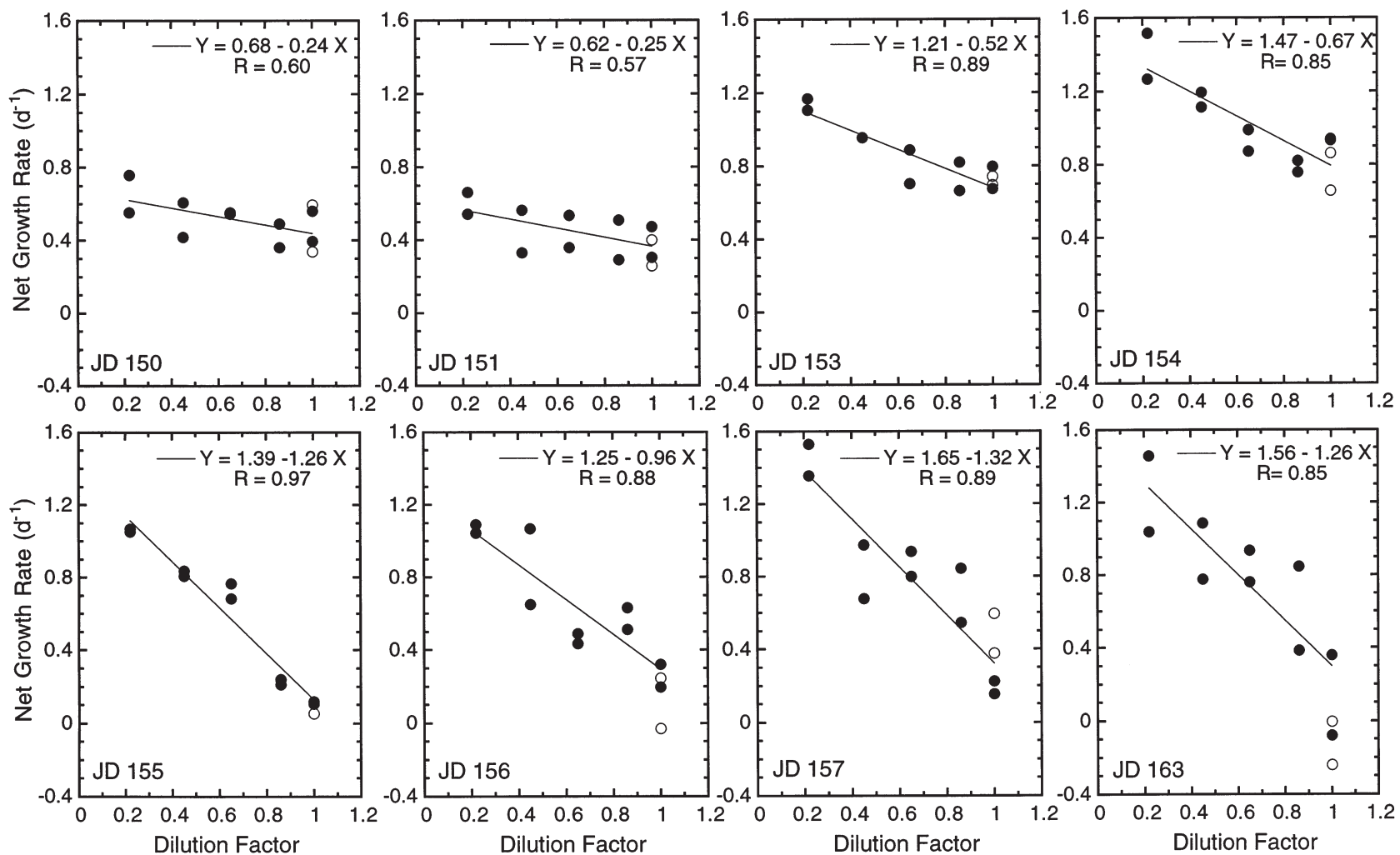

Fig. 2. Results of dilution experiments with water collected from the IronEx II patch from JDs 150 to 163 . Net growth rates from HPLC estimates of phytoplankton chl a. Regression lines are for incubations with added nutrients (•). (o) Net growth rates for undiluted samples without added nutrients

ing processes must be much lower than the tracer dilution rate. Based on these estimates for phytoplankton accumulation, mesozooplankton grazing, sinking and mixing losses, we can reasonably explain one-third to perhaps a little more than one-half of the excess growth rate observed in dilution experiments with ambient seawater. The remainder is likely due to pigment-related experimental artifacts (as discussed later).

With the results of control experiments for comparison, Fig. 2 illustrates the changes in process rates during the temporal evolution of the patch bloom. Experimental dates are the dates on which the water was collected in the patch, typically the early local morning with the experiment terminated in mid-morning on the following day. We first see little difference from control results on JDs (Julian Days) 150 and 151. Gradually, on JDs 153 and 154 (and presumably to a lesser extent on JD 152 when a patch experiment was not conducted), there was a shift to higher growth rates $\left(1.2\right.$ to $\left.1.5 \mathrm{~d}^{-1}\right)$ with little compensating increase in grazing losses. Thus, net growth rates in undiluted treatments increased to about $0.8 \mathrm{~d}^{-1}$ in the early stage of the bloom. Growth rates remained high throughout the bloom peak (JDs 155 to 158) and apparently beyond (JD 163), but the increasing slopes indicate compensating high losses to microzooplankton grazing with net community growth rates approaching zero.

The essential features of the preceding results - the similarity between control and patch rates in the initial stage of the bloom, the large increase in specific and net growth rates between JDs 152 and 154, and the increase in grazing to balance growth in the later stages of the bloom - can be illustrated in a single histogram plot (Fig. 3). This figure shows rate enhanced growth rates after the second iron addition, a growth rate declined to about $1 \mathrm{~d}^{-1}$ on JDs 155 to 156, and an increase again in response to the third and final iron fertilization.

\section{Taxon-specific rate estimates}

Table 1 lists the pigments measured in the present study and their assignments to major phytoplankton taxa. These assignments are based, in part, on known pigment compositions of the various groups (Jeffrey \& Vesk 1997), as well as relevant ancillary evidence from the study site. For example, low standing stocks of chlorophytes and cryptophytes were indicated by neg- 


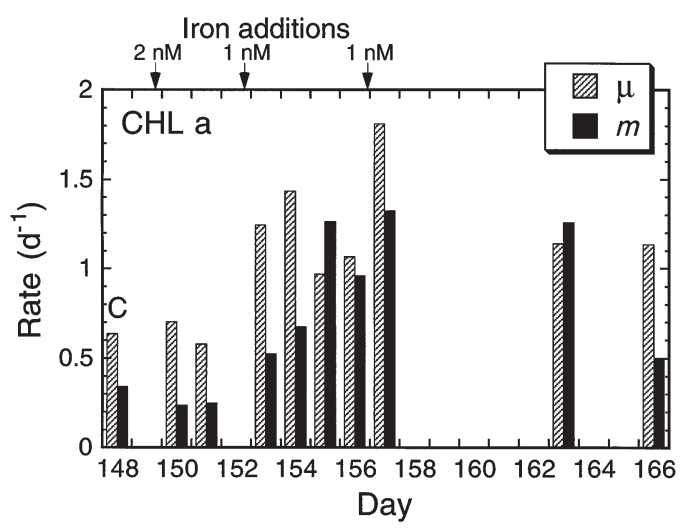

Fig. 3. Phytoplankton community growth $\left(\mu, \mathrm{d}^{-1}\right)$ and grazing mortality $\left(m, \mathrm{~d}^{-1}\right)$ estimates from chl a during the IronEx II study. ' $\mathrm{C}$ ' indicates mean of 5 'control' experiments with ambient seawater. Other histograms are results from individual dilution experiments in the iron-enriched patch on the date (Julian Day) of water collection. Each experiment integrates the rate over $24 \mathrm{~h}$ extending into the following day

ligible concentrations of their accessory pigments (lutein and alloxanthin). We thus ignored the contributions of these taxa to chl $b, \alpha$-CAR and ZEAX. These latter 3 pigments were further deduced to reside mostly in the prokaryotic picoplankton by the fact that they passed through $2 \mu \mathrm{m}$ filters in size-fractionation experiments (see also Latasa \& Bidigare 1998). Prochlorococcus spp. (PRO) can contain either monovinyl or divinyl chl $b$. In the present study, the pigment distribution was sharply divided with MVchl $b$ dominating the mixed layer and DVchl $b$ in the lower euphotic zone, presumably 2 different clones or species of PRO. Prasinophytes (PRAS) may also have contributed to MVchl $b$ and other pigments later in the patch bloom, but their main marker pigment, prasinoxanthin, was too low and variable in the earlier chromatograms to be of much use for a time course of growth and grazing rate estimates.

MVchl $a, \beta-C A R$ and DDX are broadly distributed among eukaryotic algae and are thus useful for distinguishing their combined rate responses from those of prokaryotic phytoplankton. Among the pigments with stronger group affinities, the overlap in dominant accessory pigments between prymnesiophytes (PRYMN) and pelagophytes (PELAGO) makes these groups difficult to separate unambiguously, although BUT is most strongly expressed in pelagophytes while HEX is more representative of PRYMN. PRYMN and PELAGO may also contain some fucoxanthin (FUCO), but, based on microscopical analyses, diatoms (DIAT) clearly dominated during the patch bloom.

All of the pigments believed to be associated with prokaryotic picoplankton behaved similarly in control experiments with ambient, unfertilized seawater (Table 2). Mean growth rates were low (0.15 to $\left.0.31 \mathrm{~d}^{-1}\right)$, grazing rate estimates were somewhat higher $\left(0.22\right.$ to $\left.0.41 \mathrm{~d}^{-1}\right)$, and net growth rates were low but consistently negative on average $\left(-0.07\right.$ to $\left.-0.22 \mathrm{~d}^{-1}\right)$. Inside the iron-fertilized patch, grazing losses for each of the prokaryote marker pigments showed an increasing trend, with maxima 3 to 4 times the control rate estimates between JDs 155 and 157 (Fig. 4). While dayto-day variations in grazing loss estimates were not identical for the different pigments, the general patterns were consistent. In contrast, growth rate estimates for DVchl a were markedly different from those based on other pigments. Chl $b, \alpha$-CAR and ZEAX showed increasing trends with growth estimates up to $1.2-1.5 \mathrm{~d}^{-1}$ during the peak of the patch bloom (JDs

Table 1. Taxonomic affinities of major phytoplankton pigments during the IronEx II study. Pigment-taxa assignments based on Jeffries \& Vesk (1997), as well as pigment size-fractionation and other accessory pigment information as described in text. PRO = Prochlorococcus spp., SYN = Synechococcus spp., DIAT = diatoms, DINO = dinoflagellates, PRYMN = prymnesiophytes, PRAS = prasinophytes, PELAGO = pelagophytes. Taxa believed to be dominant contributors to given pigments in the present study are underlined

\begin{tabular}{|lll|}
\hline Pigment & Abbreviation & Phytoplankton taxa \\
\hline Chl $a$ & Chl $a$ & All phytoplankton \\
Chl $b$ & Chl $b$ & $\underline{\text { PRO, PRAS }}$ \\
Divinyl chl $a$ & DVchl $a$ & $\underline{\text { PRO }}$ \\
Monovinyl chl a & MVchl $a$ & DIAT, DINO, PELAGO, PRAS, PRYM, SYN \\
$\alpha$-carotene & $\alpha$-CAR & $\underline{\text { PRO }}$, PRAS \\
$\beta$-carotene & $\beta$-CAR & $\underline{\text { PELAG DINO, PELAGO, PRYMN, SYN }}$ \\
$19^{\prime}$-butanoyloxyfucoxanthin & BUT & DIAT, DINO, PELAGO, PRYMN \\
Diadinoxanthin & DDX & $\underline{\text { DIAT, PELAGO, PRYMN }}$ \\
Fucoxanthin & FUCO & $\underline{\text { PRYMN, PELAGO }}$ \\
$19^{\prime}$-hexanoyloxyfucoxanthin & HEX & $\underline{\text { DINO }}$ \\
Peridinin & PER & $\underline{\text { PRO, SYN, PRAS }}$ \\
Zeaxanthin & ZEAX & \\
\hline
\end{tabular}


Table 2. Mean rate estimates ( \pm standard deviations) for phytoplankton growth $(\mu)$, grazing mortality $(m)$ and net growth $(k)$ for dilution experiments with ambient 'control' seawater during the IronEx II study

\begin{tabular}{|lcrrr|}
\hline Pigment & $\mu\left(\mathrm{d}^{-1}\right)$ & $m\left(\mathrm{~d}^{-1}\right)$ & $k\left(\mathrm{~d}^{-1}\right)$ \\
\hline Chl $a$ & $0.60(0.09)$ & $0.30(0.10)$ & $0.30(0.07)$ \\
Prokaryotic picoplankton & & & \\
DVchl $a$ & $0.19(0.46)$ & $0.41(0.28)$ & $-0.22(0.25)$ \\
$\alpha$-CAR & $0.31(0.34)$ & $0.39(0.26)$ & $-0.08(0.21)$ \\
Chl $b$ & $0.29(0.18)$ & $0.38(0.13)$ & $-0.09(0.11)$ \\
ZEAX & $0.15(0.36)$ & $0.22(0.14)$ & $-0.07(0.27)$ \\
Eukaryotic algae & & & & \\
MVchl a & $0.77(0.22)$ & $0.30(0.16)$ & $0.47(0.11)$ \\
$\beta$-CAR & $0.83(0.10)$ & $0.46(0.15)$ & $0.37(0.07)$ \\
DDX & $0.74(0.18)$ & $0.42(0.30)$ & $0.32(0.19)$ \\
BUT & $0.98(0.23)$ & $0.33(0.14)$ & $0.64(0.15)$ \\
FUCO & $1.42(0.16)$ & $0.61(0.26)$ & $0.81(0.25)$ \\
HEX & $0.08(0.43)$ & $-0.06(0.26)$ & $0.13(0.37)$ \\
PER & $0.70(0.64)$ & $0.68(0.33)$ & $0.03(0.38)$ \\
& & & & \\
\hline
\end{tabular}

155 to 157) while estimates based on DVchl a were lowest and negative during this same period.

Growth rates of prokaryotic picoplankton increased somewhat after the first iron fertilization (JDs 150 and 151), but a balance of growth and grazing was largely maintained (Fig. 4). In comparison, 3 broadly distributed eukaryotic pigments, MVchl $a, \beta$-CAR and DDX, suggested little or no immediate response in growth rates but reduced grazing relative to the mean rates in control experiments (Fig. 5). Mortality estimates increased for each marker pigment through the course of the bloom experiment reaching maximum levels during the bloom peak (JDs 155 to 157). High growth preceded high grazing in all cases. Rate estimates based on DDX indicated consistently high excess growth over grazing throughout the patch bloom (JDs 150 to 157), but MVchl $a$ and $\beta$-CAR suggested that a growth-grazing balance was largely achieved from JDs 155 to 163. The increased growth estimates on JD 157 for MVchl $a$ and $\beta-C A R$, but not DDX, coincided with water collected soon after the third iron addition.

Marker pigments for the dominant eukaryotic phytoplankton showed a varied range of responses to iron fertilization (Fig. 6). Significant rate (i.e., non-zero) estimates for HEX, for example, were not measured in control or early patch experiments, but they suddenly emerged as relatively high positive growth and grazing from JDs 153 to 163. Neither BUT or PER showed much of a difference in growth rates between control and patch experiments, but grazing estimates for BUT were substantially higher in the patch than controls while those for PER were not. Growth rates for diatom-associated FUCO were higher than those for other pigments, and high growth estimates for eukaryotic marker pigments (Fig. 5) followed when DIAT dominated phytoplankton biomass. The early increase in net DIAT growth from JDs 150 to 154 is reflected as slightly higher specific growth rate and lower specific grazing losses relative to control experiments. Estimates of microzooplankton grazing impact on DIAT were about double those in control experiments during the latter stages of the bloom (JDs 155 to 163), and net growth of DIAT was sharply reduced.

\section{Production and grazing relationships}

Phytoplankton growth rate estimates from the dilution incubations (Fig. 7) yielded carbon production rates similar to those from ${ }^{14} \mathrm{C}$-uptake experiments ( $\mathrm{R}$. Barber pers. comm.; data not shown). Both gave rates of 15 to $25 \mu \mathrm{g} \mathrm{C}^{-1} \mathrm{~d}^{-1}$ for the ambient community and 150 to $200 \mu \mathrm{g} \mathrm{C}^{-1} \mathrm{~d}^{-1}$ during the peak of the bloom. The independent methods also showed production increases following the third iron addition and comparable lower, but still enhanced, rate estimates for sam-
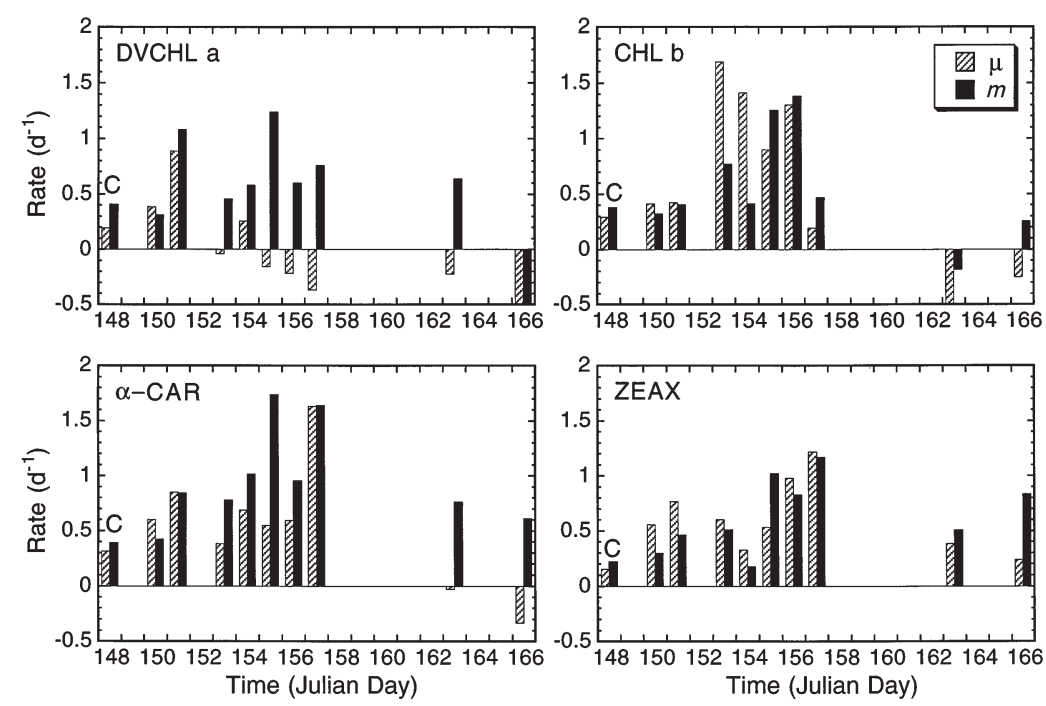

Fig. 4. Growth $(\mu)$ and grazing mortality $(m)$ estimates for pigments associated with prokaryotic pico-phytoplankton during the IronEx II study. Control experiments ' $\mathrm{C}$ ' as indicated in Fig. 3 

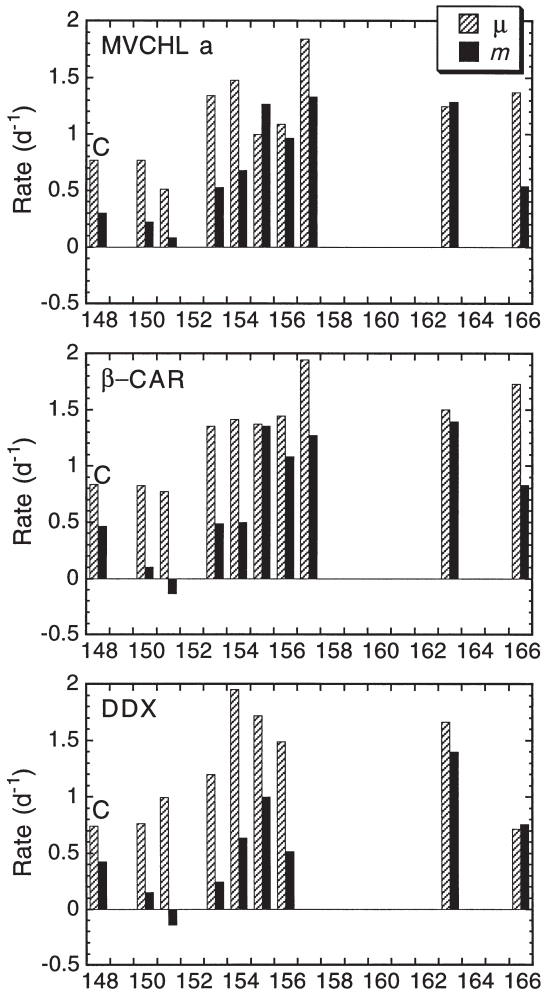

Fig. 5. Growth $(\mu)$ and grazing mortality $(m)$ estimates for pigments associated with eukaryotic algae during the IronEx II study. Control experiments ' $\mathrm{C}$ ' as indicated in Fig. 3

ples collected during the declining phase of the bloom (JDs 163 and 166). Fig. 7 shows a substantial sampling gap when the patch was abandoned in the middle of the study to pursue other work (Coale et al. 1996). We assume that the production response to the third fertilization was short lived and that the difference between growth and grazing rates closed quickly again during the period of no data. The figure also illustrates that carbon rate estimates for the phytoplankton community in the patch were highly influenced by diatoms, which averaged $79 \%$ of phytoplankton production and $55 \%$ of microzooplankton grazing losses during the peak. In comparison, diatoms constituted $17 \%$ of production and $7 \%$ of microzooplankton grazing consumption in the ambient community.

The biomass of larger $(>20 \mu \mathrm{m})$ protistan grazers increased markedly during the patch bloom, but the increase was not uniform (Fig. 8). Large heterotrophic dinoflagellates (>20 $\mathrm{mm}$ HDINO) were more abundant in the early stages of the bloom. Elevated abundances of large ciliates were evident in the present samples beginning on JD 155, but a high count on JD 153 in other sampling (Landry et al. 2000) suggests that localized increases began earlier. Ciliates dominated the $>20 \mu \mathrm{m}$ heterotrophs and may have depressed dinoflagellates during the peak of the bloom.

Overall, rate estimates of phytoplankton community grazing mortality from chl a measurements were positively correlated with total heterotrophic biovolume ( $p<0.01$, Model II reduced major axis) (Fig. 9). Grazers $>20 \mu \mathrm{m}$ were also strongly correlated with mortality of eukaryotic phytoplankton, as measured by MVchl a ( $p<0.01)$. Regression relationships between mortality coefficients of taxon-specific marker pigments and biovolumes of specific grazer size fractions were less impressive, even when significant. For instance, picoplankton mean mortality, computed as the average rate estimates for DVchl $a, \alpha-C A R$, chl $b$ and ZEAX, was well correlated with total heterotrophs $(p<0.05)$, but not significantly related to $<5 \mu \mathrm{m}$ heterotrophic flagellates $(\mathrm{R}=0.29$, not shown), their likely dominant consumers in nature (Calbet \& Landry 1999). In addition, diatom (FUCO) mortality was significantly correlated with biovolumes of $>20 \mu \mathrm{m}$ CIL and $>20 \mu \mathrm{m}$ total heterotrophs ( $\mathrm{R}=0.38$, not shown), but neither relationship explained more than $25 \%$ of the variability in the grazing rate estimates.

When grazing losses of phytoplankton carbon in Fig. 7 were normalized to the biomass of heterotrophic protists, carbon-specific grazing rates showed a steady increase from 60 to $100 \%$ of body $\mathrm{C} \mathrm{d}^{-1}$ in the ambient
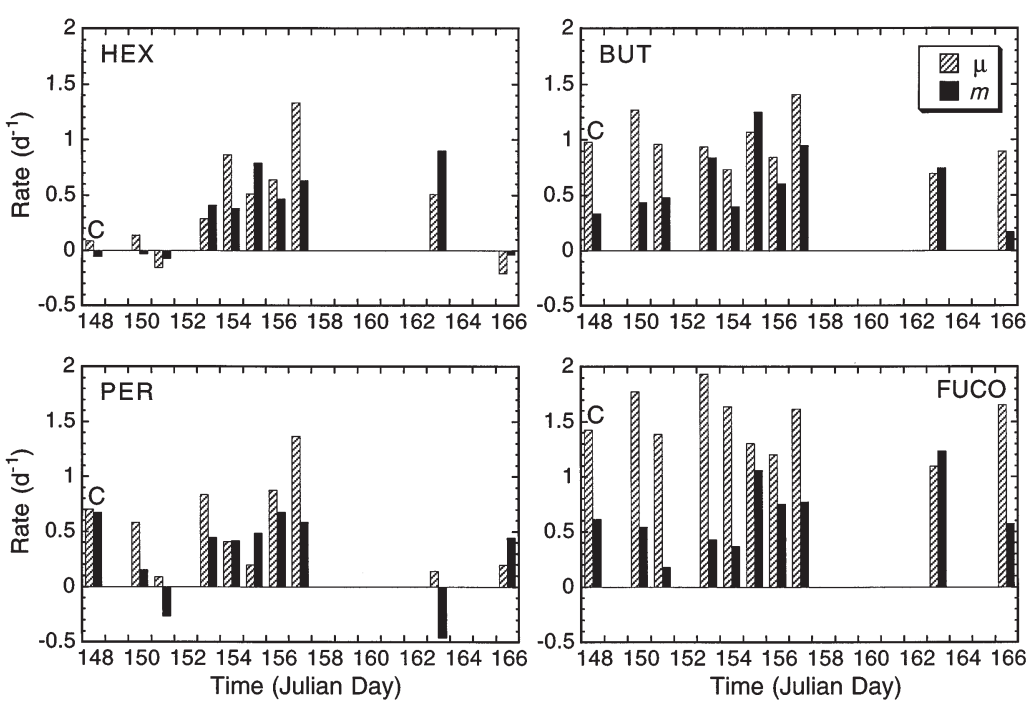

Fig. 6. Growth $(\mu)$ and grazing mortality $(m)$ estimates for taxon-specific phytoplankton pigments during the IronEx II study. Control experiments ' $\mathrm{C}$ ' averaged as in Fig. 3 


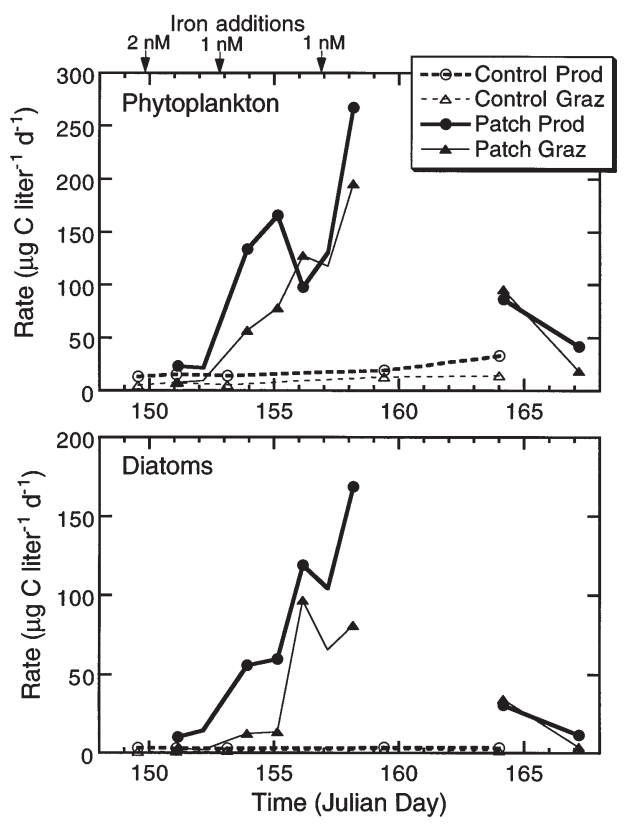

Fig. 7. Rate estimates for phytoplankton carbon production and microzooplankton carbon consumption during the IronEx II study. Phytoplankton community estimates based on chl a growth and grazing rates and measured C:chl a ratio. Diatom estimates based on FUCO growth and grazing rates and microscopically estimated diatom carbon biomass. Arrows indicate mean time of 3 iron additions to the patch

community to 8 to 9 times body $\mathrm{C} \mathrm{d}^{-1}$ during the bloom peak (Fig. 10). Corresponding rate estimates for $>20 \mu \mathrm{m}$ heterotrophs, assumed to feed exclusively on diatoms, averaged $70 \%$ of cell $\mathrm{C} \mathrm{d}^{-1}$ in control experiments and 14 times body $\mathrm{C} \mathrm{d}^{-1}$ during the bloom peak. Carbon grazing estimates for the phytoplankton community and for diatoms were both strongly correlated $(\mathrm{p}<0.01)$ with biomass of total heterotrophs and $>20 \mu \mathrm{m}$ heterotrophs, respectively (Fig. 10). However, both regressions showed substantial negative intercepts suggesting that other food resources (e.g. heterotrophic bacteria and trophic interactions among heterotrophic protists) were likely of considerable importance to the ambient community.

\section{DISCUSSION}

\section{Rate inferences from pigments}

Marker pigments are useful for analyzing multiple components of the phytoplankton community in dilution experiments (e.g. Burkill et al. 1987, Strom \& Welschmeyer 1991, Latasa et al. 1997), but some caution is needed in interpreting results. In the IronEx II study generally, pigment adaptations constituted

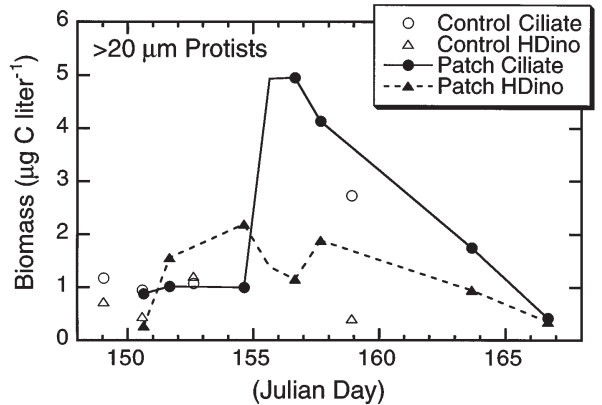

Fig. 8. Biomass estimates for $>20 \mu \mathrm{m}$ ciliates and heterotrophic dinoflagellates during the IronEx II study. Estimates based on microscopical assessments of cell abundances and biovolumes from Lugol's preserved samples collected at the start of dilution experiments

about half of the phytoplankton bloom response to iron fertilization (Landry et al. 2000). Unbalanced rates of pigment synthesis might, therefore, have overestimated cellular growth somewhat in the early stages of the bloom and possibly in experiments with ambient seawater. This latter effect would be due to inadvertent iron contamination of no-nutrient control bottles and could help to explain the relatively high net rates observed for some pigments (Table 2). However, C:chl a ratios suggest that most of the cellular pigment
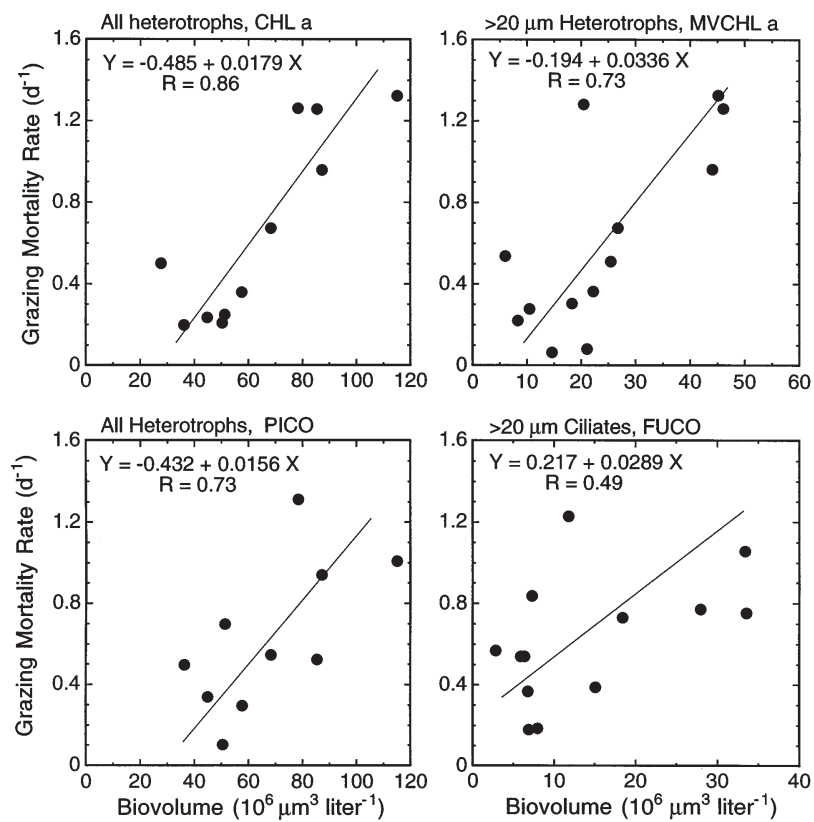

Fig. 9. Relationships between grazing mortality rate estimates for different components of the phytoplankton community and grazer biovolume. PICO is the average of mortality rate estimates for DVchl $a$, chl $b, \alpha$-CAR and ZEAX. Each of the relationships has a significant positive slope at $\geq 95 \%$ confidence level according to Model II (geometric mean, reduced major axis) regression statistics 

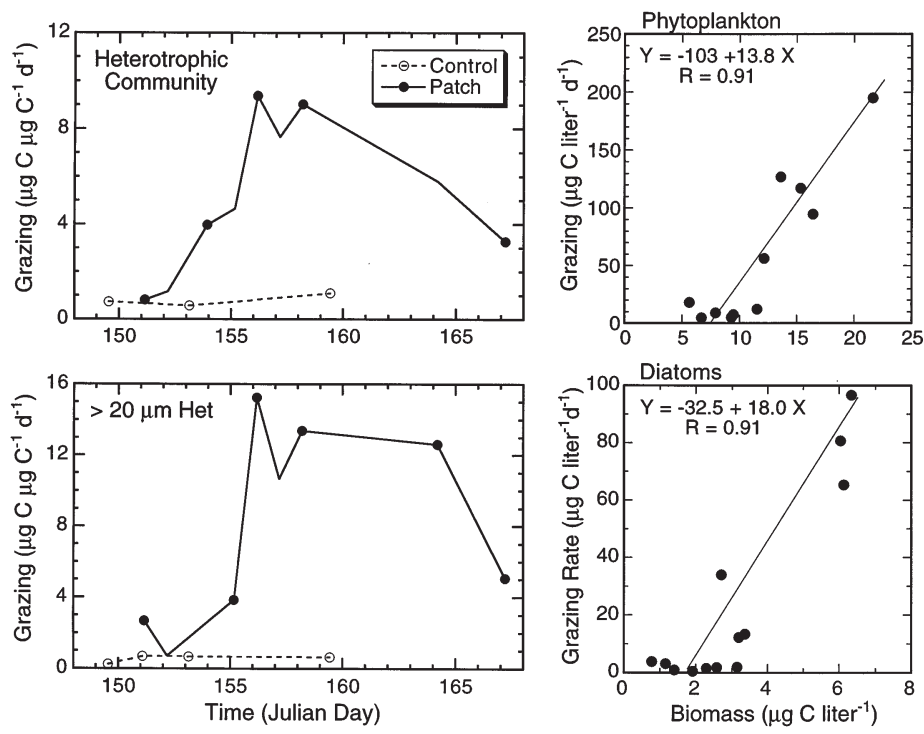

Fig. 10. Biomass-specific grazing estimates and rate relationships for total heterotrophic protists feeding on phytoplankton (top panels) and for $>20 \mu \mathrm{m}$ heterotrophs feeding on diatoms (bottom panels). Left panels show carbon-specific rate estimates for patch and control sites. Right panels show Model II liner regression (reduced major axis) relationships for carbon grazing estimates relative to carbon biomass of assumed grazers

adjustment was completed within 1 to $2 \mathrm{~d}$ of the first enrichment. Therefore, for most of the experiments conducted with patch water, we can reasonably assume that the rates were for cells already adapted to enhanced levels of iron.

Pigment adaptations to varying light level can also influence growth rate estimates and likely contributed to underestimates of PRO growth during the patch bloom, as inferred from the behavior of DVchl a. The mixed layer deepened $(50 \mathrm{~m})$ during the bloom, and mean in situ light was further reduced by the accumulated phytoplankton biomass (Rollwagen Bollens \& Landry 2000). PRO cells collected from 15 m after nighttime mixing were thus adapted to lower light levels than they experienced in the shipboard incubators, and the bleaching response was reflected in negative growth rate estimates for DVchl a. ZEAX and $\alpha$-CAR seemed to have been less sensitive to light variations, and their growth rate estimates were probably more representative of the prokaryotic populations, though not necessarily problem free.

Because light or iron effects should influence pigment synthesis (or bleaching) rates proportionately in the dilution treatments, grazing mortality estimates are less subject to errors from these factors. For example, grazing rates based on DVchl a showed a similar pattern to those for other prokaryote-related pigments, even though the growth estimates were quite different (Fig. 4). The assumptions of relatively robust mortality estimates could be violated, however, by incomplete digestive destruction of ingested pigments (e.g. Klein et al. 1986, Strom 1993). When the system was more-or-less in steady state, grazing and pigment destruction processes should have been in balance, on average. However, when the environment was changing rapidly and pigments were accumulating early in the bloom, it is possible that ingested, but not entirely digested pigments, contributed to the net growth rates measured in experimental incubations.

We have no easy explanation for the curious behavior of HEX during the control and early patch experiments. It seems unlikely that a pigment characterized by no growth or grazing could accurately reflect the dynamics of the dominant phytoplankton taxon (prymnesiophytes) in the ambient environment. If the cells were actually turning over at a fairly high rate, the lack of change in pigments in all dilution treatments could only mean that the mortality agent was inseparable from the cells themselves, e.g. cells infected with viruses or parasites. The emergence of HEX as a pigment with easily measurable rates in the middle of the patch bloom suggests a possible enhancing effect of iron, or a shift to other HEX-containing cells.

\section{Dynamics of the IronEx II bloom}

Despite certain vagaries in the interpretations of pigment changes as described above, a broad phytoplankton growth response to iron fertilization appears to be well represented in our results. As measured by chl a (Fig. 3), phytoplankton community growth rate averaged a factor of 2 higher in the patch than in ambient controls. Most marker pigments also showed elevated growth rates during the patch bloom, with picoautotrophic prokaryotes participating as well as major eukaryotic groups. This general growth enhancement is unlikely to be an experimental artifact since control rates should be most exaggerated by inadvertent iron contamination, and photobleaching should most negatively impact the rate estimates from the peak of the bloom patch (as illustrated for DVchl a). The most obvious growth rate artifacts thus work against the trend. In addition, the similarities in magnitude and timing of phytoplankton production estimates from ${ }^{14} \mathrm{C}$-uptake and dilution incubations provide general support for our rate measurements. Isotopic enrichment (up to $7 \%$ ) of the algal biomarker, phytol, was also consistent with an approximately 2-fold enhancement in phytoplankton growth rate (Bidigare et al. 1999), and FRR (Fast- 
Repetition-Rate) fluorometry indicated a 2-fold enhancement of quantum efficiencies during the extended patch bloom (Behrenfeld et al. 1996). Lastly, cell cycle analysis and diel variations in abundances and sizes of PRO indicated that growth and grazing mortality rates increased in the patch to at least $1.0 \mathrm{~d}^{-1}$ (Mann \& Chisholm 1999). Although PRO were initially believed to be constrained by synchronous cell division to growth rates of no more than $0.7 \mathrm{~d}^{-1}$ in the equatorial Pacific (Vaulot et al. 1995), these higher rates under favorable environmental conditions are consistent with recent results from the Arabian Sea (Reckermann \& Veldhuis 1997, Liu et al. 1998, Brown et al. 1999).

Based on surface area:biovolume ratios, smaller phytoplankton should be able to outcompete relatively large cells for limiting iron. Therefore, the growth response of larger cells should be greater when excess iron is added to the system. This expectation seems to be borne out if one considers net growth rates; small cells remained relatively constant while diatoms bloomed (Landry et al. 2000). Paradoxically, however, the iron enhancement effect on intrinsic growth rate was disproportionately low for diatoms relative to rate estimates for the ambient community. For experiments conducted from JDs 150 to 154, patch estimates were only $0.27 \mathrm{~d}^{-1}$ or $20 \%$ higher than mean control rates. Previous results have indicated high specific growth rates $\left(>1.0 \mathrm{~d}^{-1}\right)$ for diatoms in the equatorial Pacific (Latasa et al. 1997), so we took special care (no additions to control bottles except seawater and acid washes, and a separate set of incubation bottles for experiments with patch and ambient water) to minimize iron contamination in the present experiments. Nonetheless, if iron or some other pigment adaptation effect caused an unbalanced synthesis of FUCO in our incubation bottles, control rates may have been overestimated. If so, the actual growth rate of diatoms under ambient conditions should be no less than the measured losses attributable to microzooplankton $\left(0.6 \mathrm{~d}^{-1}\right)$ with additional modest losses $\left(\sim 0.2 \mathrm{~d}^{-1}\right)$ to mesozooplankton and sinking. At best, then, diatom growth rate increased by a factor of 2 following iron fertilization, comparable to the observed rate increase for the community as a whole. This pigment adaptation scenario would help to explain the high excess growth of diatoms in control experiments (Table 2).

Alternatively, or in addition to the above explanation, we can imagine that the relatively small $(7$ to $10 \mu \mathrm{m})$ and slender diatoms that dominate ambient waters have sufficiently high surface area:carbon ratios or other iron-acquisition mechanisms to compete favorably for the limiting resource and grow fast. The observations of Fryxell \& Kaczmarska (1994) are relevant to this point in showing high (microscopically based) cell division rates of Nitzschia spp. (averaging
$1.7 \mathrm{~d}^{-1}$ ) in trace metal clean grow-out incubations and no growth enhancement in iron-added $(2.5 \mathrm{nM})$ treatments. Accordingly, the relatively innocuous increase in diatom growth rate after iron fertilization in the present experiment could be due to larger but initially rare cells that differed from the dominant forms in being more iron limited. The available data, including FUCO-based mortality estimates and the disproportionate increase of larger diatoms in the patch (Landry et al. 2000), suggest that the accumulation of diatoms early in the bloom was as much a consequence of decreased microzooplankton grazing as increased diatom growth (Fig. 6). In effect, these somewhat larger diatoms (modal size 20 to $24 \mu \mathrm{m}$ ) may have been unavailable to the small protistan grazers in the ambient environment when iron was first added (Hansen et al. 1994). Enhanced grazing would eventually follow a short lag during which larger protistan grazers responded numerically to increased availability of appropriately sized prey.

The impact of larger protists, dinoflagellates and ciliates $>20 \mu \mathrm{m}$, is especially apparent at the peak of the bloom, when a balance between growth and grazing appears to have been achieved (Fig. 3). Particularly if one considers an additional $0.2 \mathrm{~d}^{-1}$ loss to mesozooplankton grazing (Rollwagen Bollens \& Landry 2000), there is little, if any, ungrazed phytoplankton production. Given the relative constancy of phytoplankton biomass during the bloom plateau and the high growth rate estimates, grazer regulation of phytoplankton biomass and grazer-dependent nutrient remineralization must have been central to the dynamics of phytoplankton at this time.

This does not mean that all growth phytoplankton requirements were optimal, nor does it preclude the possibility that resource limitation would play an increasingly important role in the declining phases of the patch bloom. Indeed, there is ample evidence from the phytoplankton growth response to each iron addition (Figs. $3 \&$ 7), from the diatoms' failure to express the ferredoxin protein (Erdner \& Anderson 1999) and from the gradual decline in photosynthetic efficiency following the last iron addition (Behrenfeld et al. 1996) that growth conditions were never entirely iron replete. To the extent that iron was lost from the system by vertical particle associated flux or sequestered into the growing biomass of heterotrophic bacteria (Tortell et al. 1996, Landry et al. 2000) and other pools not directly accessible to phytoplankton, growth conditions in the patch would deteriorate with time. Despite these effects, the phytoplankton remained actively growing and physiologically healthy, as opposed to senescent and moribund, through several days of peak bloom conditions. Photosynthetic efficiency remained significantly above ambient levels until almost the end 
of the patch experiment (Behrenfeld et al. 1996). As noted by Erdner \& Anderson (1999) the low-iron ferredoxin-substitute, flavodoxin, allows iron-limited phytoplankton to achieve up to $90 \%$ of their maximal growth rates. That must have been the case in the IronEx II patch, because the achieved diatom growth rates of 1.6 to $1.9 \mathrm{~d}^{-1}$ are within the range of estimates by Fryxell \& Kaczmarska (1994) and close to the expected temperature-dependent maximum (2.6 divisions $\mathrm{d}^{-1}=1.9 \mathrm{~d}^{-1}$ ) for a $12 \mathrm{~h}$ photoperiod (Eppley 1972). Erdner \& Anderson (1999) previously concluded that the IronEx II growth rates were slow relative to those of Fryxell \& Kaczmarska (1994), but this was based on comparison of maximum for diatoms versus average community (chl $a$ based) rates from the IronEx incubations.

Added iron was rapidly incorporated into new plankton biomass in the IronEx patch (Coale et al. 1996, K. Johnson pers. comm.). Therefore, sustained growth rates equivalent to 1.5 to 2 turnovers per day required high grazing rates and efficient iron remineralization (Frost \& Franzen 1992, Barbeau et al. 1996, Landry et al. 1997). Silicate concentrations in the patch also declined to levels, approximately $1 \mu \mathrm{M}$, known to severely limit the production of biogenic silica by diatoms (Brzezinski et al. 1998, Dugdale \& Wilkerson 1998), yet the population continued to grow rapidly. Recent evidence has suggested highly efficient silica remineralization $(94 \%)$ in the euphotic zone of the western equatorial Pacific (Blain et al. 1999). The present results imply that silica recycling must have also occurred at a high rate in the IronEx patch, perhaps facilitated by the high surface area of pennate frustrules, the release of individual slow settling frustrules from protistan digestive vacuoles, and accelerated microbial activity in the patch (Bidle \& Azam 1999).

\section{Grazing relationships}

The present results are somewhat disappointing with respect to the details of grazing interactions involving specific components of the protist community. While the relationships between grazing mortality of diatoms (FUCO) and $>20 \mu \mathrm{m}$ protists (ciliates or ciliates + HDINO) are statistically significant, for instance, the simple regressions explain only small amounts of the variability (Fig. 9). Measurement imprecisions no doubt contribute to the data scatter. In addition, simple relationships apparently cannot explain all of the interactive effects when predator and prey size structures, taxonomic compositions, and environmental conditions vary simultaneously.

Given an increase in mortality rates of PRO, we would have expected to find a significant relation- ship with biovolume of small heterotrophic flagellates (Calbet \& Landry 1999). The fact that experimental water and samples for $<20 \mu \mathrm{m}$ protists were usually taken from different hydrocasts may have confounded any underlying relationships, but there could be other factors as well. For example, Constantinou (1994) found that pigmented flagellates accounted for 11 to $66 \%$ of total flagellate uptake of fluorescently labeled bacteria in equatorial waters, and thus mixotrophs could make an important contribution to grazing on PRO. Adding pigmented flagellates to small heterotrophs improved the relationship between mortality rate of picophytoplankton and $<5 \mu \mathrm{m}$ flagellate biomass, but did not make it statistically significant.

It is also possible that grazing rates on picoplankton may have increased with iron addition without a proportional increase in grazer biomass. Increasing cell size (Cavender-Bares et al. 1999) should, for example, automatically increase encounter frequencies with direct interception feeders (Gonzales et al. 1990, Monger \& Landry 1990, 1991). In addition to size effects, the enhanced cell-surface hydrophobicity of PRO under certain growth conditions can approximately double grazing vulnerability to flagellate predators (Monger et al. 1999). What we know from the IronEx II experiment is that the abundances of small phytoplankton were effectively maintained within relatively narrow ranges during the patch bloom (Landry et al. 2000) and that this occurred with relatively little change in the biomass of small protistan grazers. The additional grazing impact may have been due to incidental feeding by the increased biomass of larger protists (as implied in Fig. 9, lower left). Alternatively, the mechanism(s) maintaining tightly coupled grazing interactions among the smaller components of the food web may involve subtle growth-rate dependent shifts in the physical-chemical properties of prey cells or compositional and behavioral changes within the assemblage of small grazers.

Although details of population-specific interactions are obscured by the complexities of microbial food webs, the present results yield useful information for the aggregate community. At the peak of the bloom, for example, the measured mortality rate $\left(1.2 \mathrm{~d}^{-1}=\right.$ $700 \mathrm{ml}$ cleared $\mathrm{l}^{-1} \mathrm{~d}^{-1}$ ) gives a mean biovolume-specific clearance estimate of $3 \times 10^{5} \mathrm{~h}^{-1}$ for the heterotrophic assemblage. Similarly, the mortality rate for FUCO at the peak of the bloom $\left(0.86 \mathrm{~d}^{-1}\right)$ implies a mean biovolume-specific clearance rate of $5 \times 10^{5} \mathrm{~h}^{-1}$ or $1.6 \mu \mathrm{lnd}^{-1}$ $\mathrm{h}^{-1}$ for $>20 \mu \mathrm{m}$ protists. These rates are reasonable relative to experimental results with labeled prey (Lessard \& Swift 1985, Sherr et al. 1989, 1991), and they are conservative in making no allowance for grazing by mixotrophs. It is instructive to note that the 100 -fold increase in diatom biomass early in the bloom 
does not require a similar increase in grazer biomass to bring diatoms under control. Carbon consumption by grazers does not seem to be saturated by the increase in food abundance (Fig. 10). Therefore, grazing mortality increases approximately linearly with grazer biomass, and only modest grazer increases of 2- to 5-fold are sufficient for them to consume all (or most) of daily phytoplankton production.

Carbon-specific grazing estimates for the heterotrophic community (Fig. 10) show that the growth rates of heterotrophs were significantly elevated in the patch. With consumption rate estimates of 70 to $100 \%$ of body $\mathrm{C} \mathrm{d}^{-1}$, growth rates under ambient field conditions would be substantially less than 1 cell division per day. This could be an underestimate since it ignores all trophic interactions among heterotrophs (including bacterivory); however, it also allows no consumption by mixotrophic algae. With the same caveats, the average heterotroph consumes 8 to 9 times body $\mathrm{C}$ $\mathrm{d}^{-1}$ at the peak of the bloom, which might sustain growth rates up to an order of magnitude higher than ambient. For $>20 \mu \mathrm{m}$ heterotrophs feeding on diatoms, a $30 \%$ GGE yields a growth rate of $4 \mu \mathrm{g} \mathrm{C} \mu \mathrm{g} \mathrm{C}^{-1} \mathrm{~d}^{-1}$, or 2 doublings $\mathrm{d}^{-1}\left(\mu=1.4 \mathrm{~d}^{-1}\right)$. These rough calculations indicate that increasing the food concentration for heterotrophic protists in this equatorial region can have a larger effect on their growth rates than added iron has on the growth rates of phytoplankton. Therefore, to the extent that they can capture and consume the phytoplankton that grow in response to iron fertilization, protistan grazers can rapidly attain a concentration where their grazing can match or exceed the growth rate of their phytoplankton prey. From the available evidence, we can surmise that the absence of a substantial mesozooplankton response to the patch bloom left a void that was filled by large, fast-growing protists capable of consuming and suppressing pennate diatoms. Thus, diatom production, protistan grazing and nutrient remineralization approached a dynamic balance at the peak of the bloom.

At first glance, the outcome of the IronEx II experiments would likely have been different if protistan grazing had been thwarted by the dominance of very large or spiny diatoms. However, such cells may have been selected against by the less that optimal growth conditions, including insufficient iron for ferredoxin expression (Erdner \& Anderson 1999) and low silicate concentrations. The nutrient status of the environment can therefore be assumed to have placed a significant constraint on the size structure of the responding phytoplankton assemblage. If the limited mesozooplankton response was also a general consequence of tight predatory regulation or chemical inhibition (Rollwagen Bollens \& Landry 2000), the present results may not be aberrant at all, but rather a predictable conse- quence of complex food-web regulatory mechanisms that are only beginning to be understood.

\section{Fate of iron-enhanced production}

The central issues of the iron hypothesis-that phytoplankton growth rate and standing stock are limited by iron availability and can be significantly enhanced by low level iron additions to a natural ecosystem-were convincingly demonstrated by the IronEx II study (Coale et al. 1996). To extrapolate these results to ocean carbon sequestration and potential influences on paleoclimates (Martin 1990), however, we need to consider the mechanisms and time-scales for export of iron-enhanced production from the upper oceans. Relative to biomass produced, carbon export is most efficient when phytoplankton biomass can accumulate under low grazing pressure, exhaust limiting substrate, and form fast sinking phyto-aggregates (Smetacek 1985, Alldredge et al. 1995). This appears to be a mechanism by which large Rhizosolenia spp. cells can make important contributions to carbon export in tropical oceans, including the HNLC equatorial Pacific (Sancetta et al. 1991, Yoder et al. 1994, Smith et al. 1996). If 1 grazing step is inserted into the process (e.g. copepods that produce large fast sinking fecal pellets), export is constrained by the efficiency of digestive carbon absorption and would generally not exceed $30 \%$ of POC ingested. As more layers are added to the trophic hierarchy, and particularly if the primary grazers are small, the export ratio becomes vanishingly low $(<10 \%)$, with the vast majority of consumed production respired and remineralized in the euphotic zone According to the extremes in these scenarios, carbon export can vary an order of magnitude or more for a given level of primary production depending on the structure of the grazing community (Michaels \& Silver 1988, Legendre \& LeFevre 1995, Legendre \& Rassoulzadegan 1996). This export ratio is generally thought to increase with the magnitude of primary production; therefore, the expected result of enhanced production in the IronEx II patch would be a disproportionate increase in carbon export.

The equatorial Pacific is typically a microzooplankton-dominated grazing system with high carbon remineralization and a low export ratio (Landry et al. 1997). These characteristics appear to have changed very little in the IronEx patch despite increased production and a shift to larger cells. As noted previously, physiological indices as well as various rate and standing stock measurements at the peak of the phytoplankton bloom were inconsistent with severe nutrient deficiency and mass carbon export during the bloom. Mesozooplankton stock and rate indices also suggested 
no dramatic build up in grazing potential of large zooplankton that would have significantly increased export ratios during the declining phase. In fact, losses to microzooplankton grazing accounted for a greater fraction of phytoplankton growth (96\%) at the peak of the bloom than in the ambient environment (50\%), implying that export ratios may even have declined. Both ${ }^{14} \mathrm{C}$-uptake (R. Barber pers. comm.) and dilution experiments showed a 10-fold increase in carbon production over ambient waters at the peak of the patch bloom. However, ${ }^{234}$ Th-deficiency in the patch waters (JDs 156 to 163) gave particulate export fluxes only 7 times higher than those in ambient waters (Bidigare et al. 1999). These results indicate that the export ratio multiplier did not increase, and may have decreased slightly, with enhanced production in the patch bloom. In effect, the positive feedback from nutrient remineralization remained highly efficient in the patch, as it is in the ambient environment (Landry et al. 1997), locking minerals in the euphotic zone for repeated use (Stone \& Weisburd 1992, Stone \& Berman 1993). The microplankton community thus exhibited a surprising resiliency to the perturbation caused by iron addition. Although standing stock was higher, the population responses of large protistan grazers established a new balance in which the essential features of a microzooplankton-dominated, low export system were maintained.

Over time, the increased production associated with transient nutrient inputs would have to leak out of the euphotic zone as input and export fluxes equilibrate and as phytoplankton become more nutrient stressed. Carbon export will ultimately depend on the form in which the limiting resource leaves the euphotic zone. Since iron is a highly insoluble, particle reactive element with complex chemistry, the more times that the biologically available fraction cycles through euphotic zone production, the more likely it is to exit the upper waters in an altered state (e.g. inorganic precipitate or complex), perhaps with a low complement of carbon. Similarly, if silicate provides the unique constraint on diatom standing stock and productivity, the magnitude of diatom-associated carbon export and the extent of its penetration into the inner oceans will vary greatly depending on whether silica exits the upper waters as empty frustrules, silica-enriched fecal pellets or intact cells (Dugdale et al. 1995, Brzezinski et al. 1998). The IronEx II study was not designed to elucidate export mechanisms and fluxes nor was the declining phase of the patch bloom sampled sufficiently well to draw clear inferences about these processes. Given the importance of such knowledge to a better understanding of ocean biogeochemistry and as input to global climaterelevant models, advancements in this area would be a fruitful and challenging emphasis for future experimental manipulations of open-ocean ecosystems.
Acknowledgements. We gratefully acknowledge the efforts of Kenneth Coale, Ken Johnson and staff at the Moss Landing Marine Laboratories for organizing the IronEx II expedition and all those in the science team and RV 'Melville' crew who contributed to the success of the study. This portion of the study was supported, in part, by National Science Foundation Grants OCE-9022117 and -9218152 to MRL and -9022321 to RRB. Contributions No. 5239 from the School of Ocean and Earth Science and Technology, University of Hawai'i at Manoa, Honolulu, Hawai'i 96822, USA, and No. 561 from the US JGOFS Program.

\section{LITERATURE CITED}

Alldredge AL, Gotschalk C, Passow U, Riebesell U (1995) Mass aggregation of diatom blooms: insights from a mesocosm study. Deep-Sea Res II 42:9-29

Barbeau, K, Moffett JW, Caron DA, Croot PL, Erdner DL (1996) Role of protozoan grazing in relieving iron limitation of phytoplankton. Nature 380:61-64

Behrenfeld MJ, Bale AJ, Kolber ZS, Aiken J, Falkowski PG (1996) Confirmation of iron limitation of phytoplankton photosynthesis in the equatorial Pacific Ocean. Nature 383:508-511

Bidigare RR, Hanson KL, Buesseler K, Wakeham SG, Freeman KH, Pancost RD, Millero FJ, Steinberg P, Popp BN, Latasa M, Landry MR, Laws EA (1999) Iron-stimulated changes in ${ }^{13} \mathrm{C}$ fractionation and export by equatorial Pacific phytoplankton: toward a paleo-growth rate proxy. Paleoceanography 14:589-595

Bidle KD, Azam F (1999) Accelerated dissolution of diatom silica by marine bacterial assemblages. Nature 397:508-512

Blain S, Tréguer, Rodier M (1999) Stocks and fluxes of biogenic silica in the western oligotrophic equatorial Pacific. J Geophys Res 104:3357-3368

Brown SL, Landry MR, Barber RT, Campbell L, Garrison DL, Gowing MM (1999) Picophytoplankton dynamics and production in the Arabian Sea during the 1995 Southwest Monsoon. Deep-Sea Res II 46:1745-1768

Brzezinski MA, Villareal TA, Lipschultz F (1998) Silica production and the contribution of diatoms to new and primary production in the central North Pacific. Mar Ecol Prog Ser 167:89-104

Burkill PH, Mantoura RFC, Llewellyn CA, Owens NJP (1987) Microzooplankton grazing and selectivity of phytoplankton in coastal waters. Mar Biol 93:581-590

Calbet A, Landry MR (1999) Mesozooplankton influences on the microbial food web: direct and indirect trophic interactions in the oligotrophic open-ocean. Limnol Oceanogr 44:1370-1380

Cavender-Bares KK, Mann EL, Chisholm SW, Ondrusek ME, Bidigare RR (1999) Differential response of equatorial Pacific phytoplankton to iron fertilization. Limnol Oceanogr 44:237-246

Coale KH, Johnson KS, Fitzwater SE, Gordon RM, Tanner S, Chavez FP, Ferioli L, Sakamoto C, Rogers P, Millero F, Steinberg $\mathrm{P}$, Nightingale $\mathrm{P}$, Cooper D, Cochlan WP, Landry MR, Constantinou J, Rollwagen G, Trasvina A, Kudela R (1996) A massive phytoplankton bloom induced by an ecosystem-scale iron fertilization experiment in the equatorial Pacific Ocean. Nature 383:495-501

Constantinou J (1994) Mixotrophic nanoflagellates in marine microbial food webs. MS thesis, Department of Oceanography, University of Hawai'i at Manoa

Cullen JJ (1991) Hypotheses to explain high-nutrient conditions in the open sea. Limnol Oceanogr 40:1336-1343

Dugdale RC, Wilkerson FP (1998) Silicate regulation of new 
production in the equatorial Pacific upwelling. Nature 391:2870-273

Dugdale RC, Wilkerson FP, Minas HP (1995) The role of a silicate pump in driving new production. Deep-Sea Res II 42:697-719

Erdner DL, Anderson DM (1999) Ferredoxin and flavodoxin as biochemical indicators if iron limitation during openocean iron-enrichments. Limnol Oceanogr 44:1609-1615

Eppley RW (1972) Temperature and phytoplankton growth in the sea. Fish Bull US 70:1063-1085

Fitzwater SE, Knauer GA, Martin JH (1982) Metal contamination and its effect on primary production measurements. Limnol Oceanogr 27:544-551

Frost BW (1972) Effects of size and concentration of food particles on the feeding behavior of the marine planktonic copepod Calanus pacificus. Limnol Oceanogr 17:805-815

Frost BW, Franzen NC (1992) Grazing and iron limitation in the control of phytoplankton stock and nutrient concentration: a chemostat analogue of the Pacific equatorial upwelling zone. Mar Ecol Prog Ser 83:291-303

Fryxell GA, Kaczmarska I (1994) Specific variability in Feenriched cultures from the equatorial Pacific. J Plankton Res 16:755-769

Gonzales JM, Sherr EB, Sherr BF (1990) Size-selective grazing on bacteria by natural assemblages of estuarine flagellates and ciliates. Appl Environ Microbiol 56:583-589

Greene RM, Kolber ZS, Swift DG, Tindale NW, Falkowski PG (1994) Physiological limitation of phytoplankton photosynthesis in the Eastern Equatorial Pacific determined from variability of the quantum yield of fluorescence. Limnol Oceanogr 39:1061-1074

Hansen B, Bjørnsen PK, Hansen PJ (1994) The size ratio between planktonic predators and their prey. Limnol Oceanogr 39:395-403

Jeffrey SW, Vesk M (1997) Introduction to marine phytoplankton and their pigment signatures. In: Jeffrey SW, Mantoura RCF, Wright SW (eds) Phytoplankton pigments in oceanography: guidelines to modern methods. UNESCO Publishers, Paris, p 37-82

Klein B, Gieskes WWC, Kraay GG (1986) Digestion of chlorophylls and carotenoids by the marine protozoan Oxyrrhis marina studied by h.p.l.c. analysis of algal pigments. J Plankton Res 8:827-836

Kolber ZS, Barber RT, Coale KH, Fitzwater SE, Greene RM, Johnson KS, Lindley S, Falkowski PG (1994) Iron limitation of phytoplankton photosynthesis in the equatorial Pacific Ocean. Nature 731:145-149

Landry MR (1981) Switching between herbivory and carnivory by the planktonic marine copepod Calanus pacificus. Mar Biol 65:77-82

Landry MR (1993) Estimating rates of growth and grazing mortality of phytoplankton by the dilution method. In: Kemp PF, Sherr BF, Sherr EB, Cole JJ (eds) Handbook of methods in aquatic microbial ecology. Lewis Publishers, Boca Raton, p 715-722

Landry MR, Hassett RP (1982) Estimating the grazing impact of marine microzooplankton. Mar Biol 67:283-288

Landry MR, Constantinou J, Kirshtein J (1995) Microzooplankton grazing in the central equatorial Pacific during February and August 1992. Deep-Sea Res II 42:657-671

Landry MR, Barber RT, Bidigare RR, Chai F, Coale KH, Dam HG, Lewis MR, Lindley ST, McCarthy JJ, Roman MR, Stoecker DK, Verity PG, White JR (1997) Iron and grazing constraints on primary production in the central equatorial Pacific: an EqPac synthesis. Limnol Oceanogr 42:405-418

Landry MR, Brown SL, Campbell L, Constantinou J, Liu H (1998) Spatial patterns in phytoplankton growth and microzooplankton grazing in the Arabian Sea during monsoon forcing. Deep-Sea Res II 45:2353-2368

Landry MR, Ondrusek ME, Tanner SJ, Brown SL, Constantinou J, Bidigare RR, Coale KH, Fitzwater S (2000) Biological response to iron fertilization in the eastern equatorial Pacific (IronEx II). I. Microplankton community abundances and biomass. Mar Ecol Prog Ser 201:27-42

Latasa M, Bidigare RR (1998) A comparison of phytoplankton populations of the Arabian Sea during the Spring Intermonsoon and Southwest Monsoon of 1995 as described by HPLC-analyzed pigments. Deep-Sea Res II 45:2133-2170

Latasa M, Bidigare RR, Ondrusek ME, Kennicutt MC II (1996) HPLC analysis of algal pigments: a comparison exercise among laboratories and recommendations for improved analytical performance. Mar Chem 51:3115-3124

Latasa M, Landry MR, Schülter L, Bidigare RR (1997) Pigment-specific growth and grazing rates of phytoplankton in the central equatorial Pacific. Limnol Oceanogr 42: 289-298

Legendre L, Le Fèvre J (1995) Microbial food webs and the export of biogenic carbon in the oceans. Aquat Microb Ecol 9:69-77

Legendre L, Rassoulzadegan F (1996) Food-web mediated export of biogenic carbon in oceans: hydrodynamic control. Mar Ecol Prog Ser 145:179-193

Lessard E (1991) The trophic role of heterotrophic dinoflagellates in diverse marine environments. Mar Microb Food Webs 5:49-58

Lessard EJ, Swift E (1985) Species-specific grazing rates of heterotrophic dinoflagellates in oceanic waters, measured with a dual-label radioisotope technique. Mar Biol 87: 289-296

Li WKW (1990) Particles in 'particle-free' seawater: growth of ultraplankton and implication for dilution experiments. Can J Fish Aquat Sci 47:1258-1268

Liu H, Campbell L, Landry MR, Nolla HA, Brown SL, Constantinou J (1998) Prochlorococcus and Synechococcus growth rates and contributions to production in the Arabian Sea during the 1995 Southwest and Northeast Monsoons. Deep-Sea Res II 45:2327-2352

Mackey MD, Mackey DJ, Higgins HW, Wright SW (1996) CHEMTAX - a program for estimating class abundances from chemical markers: application to HPLC measurements of phytoplankton. Mar Ecol Prog Ser 144:265-283

Mann EL, Chisholm SW (1999) The growth rate of Prochlorococcus in the eastern equatorial Pacific is limited by iron. Am Soc Limnol Oceanogr, Santa Fe, Abstr Aquat Sci Mtg, p 116

Martin JH (1990) Glacial-interglacial $\mathrm{CO}_{2}$ change: the iron hypothesis. Paleoceanography 5:1-13

Martin JH, Coale KH, Johnson KS, Fitzwater SE, Gordon RM, Tanner SJ, Hunter CN, Elrod VA, Nowicki JL, Coley TL, Barber RT, Lindley S, Watson AJ, Van Scoy K, Law CS, Liddicoat MI, Ling R, Stanton T, Stockel J, Collins C, Anderson A, Bidigare R, Ondrusek M, Latasa M, Millero FJ, Lee J, Yao W, Zhang JZ, Friederich G, Sakamoto C, Chavez F, Buck K, Kolber Z, Greene R, Falkowski P, Chisholm SW, Hoge F, Swift R, Yungel J, Turner S, Nightingale P, Hatton A, Liss P, Tindale NW (1994) Testing the iron hypothesis in ecosystems of the equatorial Pacific Ocean. Nature 371:123-129

Michaels AF, Silver MW (1988) Primary production, sinking fluxes and the microbial food web. Deep-Sea Res 35: 473-490

Monger BC, Landry MR (1990) Direct-interception feeding by marine zooflagellates: the importance of surface and hydrodynamic forces. Mar Ecol Prog Ser 65:123-140 
Monger BC, Landry MR (1991) Prey-size dependency of grazing by free-living marine flagellates. Mar Ecol Prog Ser 74:239-248

Monger BC, Landry MR, Brown SL (1999) Feeding selection of heterotrophic marine nanoflagellates based on the surface hydrophobicity of their picoplankton prey. Limnol Oceanogr 44:1917-1927

Morel FMM, Rueter JG, Price NM (1991) Iron nutrition of phytoplankton and its possible importance in the ecology of open ocean regions with high nutrient and low biomass. Oceanography 4:56-61

Price NM, Ahner BA, Morel FMM (1994) The equatorial Pacific Ocean: grazer-controlled phytoplankton populations in an iron-limited ecosystem. Limnol Oceanogr 39:520-534

Putt M, Stoecker DK (1989) An experimentally determined carbon:volume ratio for marine 'oligotrichous' ciliates from estuaries and coastal waters. Limnol Oceanogr 34:1097-1103

Reckermann M, Veldhuis MJW (1997) Trophic interactions between picophytoplankton and micro- and nanozooplankton in the western Arabian Sea during the NE monsoon 1993. Aquat Microb Ecol 12:263-273

Rollwagen Bollens GC, Landry MR (2000) Biological response to iron fertilization in the eastern equatorial Pacific (IronEx II). II. Mesozooplankton abundance, biomass, depth distribution and grazing. Mar Ecol Prog Ser 201:43-56

Sancetta C, Villareal T, Falkowski P (1991) Massive fluxes of rhisosolenid diatoms: a common occurrence? Limnol Oceanogr 36:1457-1462

Sherr EB, Rassoulzadegan F, Sherr BF (1989) Bacterivory by pelagic choreotrichous ciliates in coastal waters of the NW Mediterranean Sea. Mar Ecol Prog Ser 55:235-240

Editorial responsibility: Otto Kinne (Editor), Oldendorf/Luhe, Germany
Sherr EB, Sherr BF, McDaniel J (1991) Clearance rates of $<6 \mu \mathrm{m}$ fluorescently labeled algae (FLA) by estuarine protozoa: potential grazing impact of flagellates and ciliates. Mar Ecol Prog Ser 69:81-92

Smetacek V (1985) Role of sinking in diatom life-history cycles: ecological, evolutionary and geological significance. Mar Biol 84:239-251

Smith CR, Hoover DJ, Doan SE, Pope RH, DeMaster DJ, Dobbs FC, Altabet MA (1996) Phytodetritus at the abyssal seafloor across $10^{\circ}$ of latitude in the central equatorial Pacific. Deep-Sea Res II 43:1309-1338.

Stone L, Berman T (1993) Positive feedback in aquatic ecosystems: the case of the microbial loop. Bull Math Biol 55: 919-936

Stone L, Weisburd RJS (1992) Positive feedback in aquatic ecosystems. Trends Ecol Evol 7:263-267

Strom SL (1993) Production of phaeopigments by marine protozoa: results of laboratory experiments analyzed by HPLC. Deep-Sea Res 40:57-80

Strom SL, Welschmeyer NA (1991) Pigment-specific rates of phytoplankton growth and microzooplankton grazing in the open subarctic Pacific Ocean. Limnol Oceanogr 36: $50-63$

Tortell PD, Maldonado MT, Price NM (1996) The role of heterotrophic bacteria in iron-limited ocean ecosystems. Nature 383:330-332

Vaulot D, Marie D, Olson RJ, Chisolm SW (1995) Growth of Prochlorococcus, a photosynthetic prokaryote, in the equatorial Pacific Ocean. Science 268:1480-1482

Yoder JA, Ackelson SG, Barber RT, Flament P, Balch WM (1994) A line in the sea. Nature 371:689-692

Submitted: July 7, 1999; Accepted: December 15, 1999 Proofs received from author(s): July 12, 2000 